\title{
NCOA6 Gene
}

National Cancer Institute

\section{Source}

National Cancer Institute. NCOA6 Gene. NCI Thesaurus. Code C20702.

This gene plays a role in the transcriptional activation of target genes. 